\title{
Por uma história das práticas de cura
}

\author{
Towards a bistory of curing practices \\ Magali Gouveia Engel \\ Professora do Departamento de História da UFF \\ Rua Três, Quad.4, L 6 - Condominio Uba-Pendotiba \\ 24322-140 Niterói - RJ \\ magali5@uol.com.br
}

Dizem que foi feitiço: as práticas da cura no sul do Brasil (1845 a 1880)

Nikelen Acosta Witter, Porto Alegre,

EDIPUCRS, 2001
$\mathrm{O}$ riginalmente dissertação de mestrado defendida no Programa de Pós-Graduação em História da Pontifícia Universidade Católica do Rio Grande do Sul, o livro de Nikelen Acosta Witter representa inegavelmente uma contribuição original e bastante relevante no âmbito da história da medicina, ou, como prefere a autora, da 'história da cura', no Brasil. O estudo tem como eixo central a história de Maria Antônia, que se desenrola em meados do século XIX, na localidade de Santa Maria da Boca do Monte, província do Rio Grande do Sul. Não se trata, contudo, como salienta a própria autora, de um 'estudo de caso' - de Santa Maria ou de Maria Antônia, mas de uma excelente análise, tecida sob a inspiração das concepções de Giovanni Levi ${ }^{1}$, a partir da articulação consistente entre as dimensões macro e micro do processo histórico, na qual o objeto e suas problemáticas são muito bem construídos e devidamente contextualizados. Além disso, a narrativa se desenvolve de forma dinâmica e interessante, conduzindo o leitor a refletir sobre as inúmeras questões levantadas pela investigação, constantemente propostas pela autora.

Assim, partindo da história de uma negra alforriada que, apesar de possuir o ofício de roceira, tinha sua sobrevivência assegurada sobretudo pelos ganhos obtidos como uma das mais respeitadas e famosas curandeiras da região, Nikelen Witter debruça-se sobre as "relações que se estabeleciam entre a cura, a doença e os agentes da cura com os homens e as mulheres" (p. 21) que habitavam a região de Santa Maria, compreendendo-as não apenas através de sua própria dinâmica, mas também de sua inserção no 'contexto maior' daquele tempo. Os processos criminais constituem o núcleo central da variada documentação utilizada, que inclui atas e correspondências da Câmara de Vereadores de Santa Maria da Boca do Monte e relatórios dos presidentes da província do Rio Grande do Sul. Foi justamente por intermédio de um desses processos que Nikelen interessou-se pelo caso de Maria Antônia, acusada em 1866 de ter envenenado a jovem Henriqueta, filha de um casal de lavradores pobres da região. Perfeitamente adequados aos objetivos traçados pela autora, os registros judiciais configuram um tipo de fonte que, como sabemos, apresenta riquíssimo potencial, mas também algumas dificuldades específicas em sua exploração. Entre estas, destaco as controvérsias sobre o caráter fictício dos resultados finais dos inquéritos judiciais. Nikelen nega que se possa considerá-los uma fábula²:

\footnotetext{
${ }^{1}$ Levi, G., 'Sobre micro-história'. Em G. Levi. A escrita da história, São Paulo, Unesp, 1992.

${ }^{2} Z$ Zenha, C., 'As práticas da justiça no cotidiano da pobreza'. Revista Brasileira de História, vol. 5, no 10 mar./ago. 1985
} 
... por mais inventivo que pareça ser o resultado dos depoimentos, este não pode ser comparado à fantasia porque, de qualquer forma, ele lida com o que é possível de ser verossímil, nada do que está presente nos autos pode fugir ao que o bom senso determina que poderia ser realidade, mesmo que seja invenção (p. 54).

A análise desenvolvida pela autora tem como referência uma bibliografia ${ }^{3}$ que, através de 'novas abordagens', problematiza as vertentes da história da medicina que reúnem de um lado, "obras de cunho evolucionista e laudatório" (p. 14) e de outro investigações centradas na relação entre saberes e poderes médicos e estratégias de disciplinarização — inspiradas, sobretudo, nas concepções de Michel Foucault. Nesse sentido, traz inovações preciosas para os estudos desenvolvidos no âmbito desse campo de investigação, ao adotar, por exemplo, uma perspectiva que reconhece a multiplicidade dos saberes e das práticas de cura existentes na sociedade oitocentista, recusandose a hierarquizá-los. Segundo Nikelen,

Trata-se de ver o curandeirismo ou as práticas de cura populares não como um fenômeno que se constrói em oposição ou para cobrir os espaços deixados pela medicina, mas como conjuntos de saberes criados pela experiência e preservados pela tradição, os quais teriam sempre um espaço na cultura dos povos, muito antes do advento da medicina acadêmica (p. 19).

Há, contudo, uma certa mistificação das 'produções mais recentes', às vezes referendadas como marcos inaugurais de reflexões e concepções absolutamente novas, fazendo tábula rasa de toda a produção 'anterior'. Corre-se pois o risco de comprometer a percepção da construção do conhecimento como um processo histórico e, portanto, dinâmico, perma-nentemente atravessado por tensões e disputas. E também de reconhecer que qualquer conhecimento, por mais renovador e revolucionário que possa ser, parte sempre de saberes coletivos e plurais acumulados. A preocupação com a historicidade da palavra medicina, por exemplo, partilhada pela autora com Beatriz Weber, remete a questões cruciais formuladas por Michel Foucault, cujas idéias inspiraram algumas das correntes da história da medicina criticadas e rejeitadas pelas novas vertentes.

A contribuição mais original e importante do trabalho de Nikelen referese, ao meu ver, à sua recusa em conceber o recurso de diversos segmentos sociais a outros saberes e práticas de cura não-oficiais e/ou acadêmicos como resultado de uma 'lacuna', produzida pela 'falta' de profissionais formados em faculdades de medicina e instituições de assistência médica, bem como pela 'precariedade' das ações públicas no campo da saúde. Tais atitudes são vistas pela autora como 'opções' resultantes de diferentes formas de conceber a doença e com ela lidar, difundidas pelo conjunto da população da sociedade imperial. Deste modo, são compreendidas como ações afirmativas — e não puramente de reação a algo supostamente melhor,

${ }^{3}$ Por exemplo, Chalhoub, S., Cidade febril: cortiços e epidemias na Corte Imperial, São Paulo, Companhia das Letras, 1996; Weber, B., As artes de curar: medicina, religião, magia e positivismo na república rio-grandense, 1889-1928, Santa Maria, Edusc/Ed. da UFSM, 1999. 
mais verdadeiro e mais eficiente - e, portanto, a partir de sua 'positividade'.

Por outro lado, é possível surpreender a presença de resquícios de uma perspectiva informada pela ótica evolucionista em afirmações como, por exemplo: "Ao longo dos oitocentos, como não houvesse, ... um domínio sobre o que era 'a verdade' nos tratamentos das moléstias, uma grande quantidade de práticas curativas disputava espaços junto aos doentes" (p. 24). A pluralidade de alternativas de 'formas de curar' aparece, assim, como decorrente da própria ineficiência da medicina científica do século XIX, tão incerta e frágil como os demais saberes e práticas de cura. Parece-me que tal concepção acaba também por alimentar uma certa memória da medicina acadêmica que afirma suas supostas conquistas no sentido de monopolizar as verdades sobre a doença e a saúde, como frutos do 'progresso' dos tempos. Apagam-se ou pelo menos secundarizam-se as tensões e os conflitos entre outras alternativas de cura hoje presentes, conferindo à medicina científica e acadêmica um lugar exclusivo e incontestável no topo da hierarquia dos diversos saberes e práticas de cura.

De qualquer forma, a ressalva não compromete a riqueza e a profundidade da análise realizada pela autora. Levando em conta a pluralidade e a complexidade das idéias e das experiências diante da doença, essa análise situa os confrontos entre elas e discute seus possíveis significados e desdobramentos históricos na segunda metade do século XIX. Os móveis que teriam levado os pais de Henriqueta a recorrer a diversos curadores como a 'preta' Maria Antônia, a 'índia' Maria Nungá, o cirurgião-mor da Guarda Nacional Francisco Custódio da Silva e o médico homeopata Theobaldo Jaeger — , bem como as possíveis razões que teriam produzido a culpabilização de Maria Antônia são buscados a partir de uma perspectiva que preza a complexidade, rompendo com explicações simplistas que apontam respostas únicas, homogêneas e estáticas.

Enfim, em seu brilhante estudo, Nikelen Witter consegue cumprir de forma plena e competente seus objetivos centrais de investigar e compreender "as formas pelas quais se articulavam as visões acerca da doença, da cura e dos agentes da cura nas experiências de homens e mulheres" (p. 13) que viviam em Santa Maria da Boca do Monte, na segunda metade do século XIX.

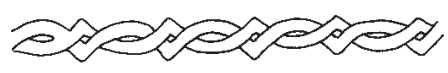

